\title{
NOTE
}

\section{Virus susceptibility of the fish cell line SAF-1 derived from gilt-head seabream}

\author{
S. I. Perez-Prieto ${ }^{1}$, S. Rodriguez-Saint-Jean ${ }^{1}$, E. Garcia-Rosado ${ }^{2}$, D. Castro ${ }^{2}$, M. C. Alvarez ${ }^{3}$, \\ J. J. Borrego ${ }^{2, *}$ \\ ${ }^{1}$ Centro de Investigaciones Biológicas, C.S.l.C., Velázquez, 144, E-28006 Madrid, Spain \\ ${ }^{2}$ Departamento de Microbiología and ${ }^{3}$ Departamento de Biología Celular y Genética, Facultad de Ciencias, Universidad de Málaga, \\ E-29071 Málaga, Spain
}

\begin{abstract}
The recently reported SAF-1 cell line from fins of gilt-head seabream was evaluated for susceptibility to lymphocystis disease virus (LDV) and to several salmonid fish viruses, such as infectious haematopoietic necrosis virus (IHNV), viral haemorrhagic septicemia virus (VHSV) and several strains of infectious pancreatic necrosis virus (IPNV). LDV, VHSV and IHNV replicated well in the cultured fin cells as demonstrated by cell lysis and increases in viral titer. The potential use of this cell line to detect viruses from fish marine species is discussed
\end{abstract}

KEY WORDS: Fish viruses Lymphocystis - Fish cell lines SAF-1 - Gilt-head seabream

Lymphocystis disease is a common chronic benign viral infection of a wide variety of marine and brackish water teleost fish with an almost world-wide geographical distribution (Walker \& Hill 1980, Berthiaume et al. 1984, Anders 1989). The disease is characterized by the development of nodules or clusters of tumourlike appearance on the skin and fins of infected fish (Nigrelli \& Smith 1939), provoked by the growth of abnormally enlarged cells containing viral particles in their cytoplasm (Wolf 1988). Although infected fish appear unsightly, the disease is rarely fatal (Templeman 1965), and under aquaculture conditions no significant mortality rate has been recorded (Tanaka et al. 1984, Masoero et al. 1986). Lymphocystis viruses, belonging to the family Iridoviridae (Fenner 1976), have been successfully assayed and quantified by TCID $_{50}$ and ID $_{50}$ methods using the bluegill cell line BF-2 (Wolf et al. 1986). However, in this cell line a com-

- Addressee for correspondence.

E-mail: jjborrego@ccuma.uma.es plete replication of the virus is not achieved, and, therefore, it is not a sensitive and accurate system for subculture and enumeration (Walker \& Hill 1980).

In recent years, gilt-head seabream Sparus aurata L. has emerged as the most important species in the fish aquaculture of the European Mediterranean countries, and therefore much attention has been paid to improve the production of this species by breeding and by disease control. Lymphocystis disease is the only described viral infection affecting this fish species (Paperna et al. 1982). However, the in vitro effects of pathogenic microorganisms affecting gilt-head seabream have been carried out on heterologous fish cell cultures, from marine and freshwater fish species. For this reason, the establishment of a homologous and stable gilthead seabream cell line is desirable for the purpose of detecting specific pathogens, especially viruses, and evaluating the role of this fish species as asymptomatic carrier of different viruses that might affect other commercially cultured fish, such as salmonids, turbot and sole.

Recently, Bejar et al. (1997) described a new continuous cell line from fins of gilt-head seabream, named SAF-1. The scope of the present work is to determine the susceptibility of the SAF-1 cell line to several viruses repeatedly found in Spain in different cultured fish (Basurco et al. 1990, Perez \& Rodriguez 1997, Rodriguez et al. 1997). If SAF-1 proved to be susceptible to a wide variety of marine fish viruses, then it would be possible to carry out virological surveys of populations of gilt-head seabream cultured in Southern Spain as recommended by the European Union (Bruno et al. 1997) prior to the fish export.

Material and methods. Cell lines: BF-2 from bluegill fry (ATCC CCL91) was used to culture all the viruses 
tested. Cells were propagated in Eagle's Minimum Essential medium (MEM) (Flow, Scotland, UK) supplemented with $10 \%$ foetal bovine serum (FBS) (Flow), L-glutamine (10 $\mathrm{mM})$, and penicillin (100 IU $\left.\mathrm{ml}^{-1}\right)$ and streptomycin $\left(100 \mu \mathrm{g} \mathrm{ml}^{-1}\right)(\mathrm{P}+\mathrm{S})$, and buffered with $0.15 \mathrm{mM}$ Hepes (Flow). The cells were propagated at $20^{\circ} \mathrm{C}$ in 25 or $75 \mathrm{~cm}^{2}$ tissue culture flasks (Costar). In open cell culture systems, Leibowitz (L-15) medium (Flow) with $10 \%$ FBS and $\mathrm{P}+\mathrm{S}$ was used.

The cell line SAF-1 from gilt-head seabream was cultured as previously described by Bejar et al. (1997) using Dulbecco's Modified Eagle's medium/Nutrient Mixture Ham's F12 (DME/F12) (Sigma Chemical Co., St. Louis, MO) medium (pH 7.2) supplemented with $5 \%$ FBS, $2 \%$ L-glutamine, and $1 \%$ of an antibiotic/ antimycotic solution (100 IU penicillin $\mathrm{G} \mathrm{ml}^{-1}, 10 \mu \mathrm{g}$ $\mathrm{ml}^{-1}$ streptomycin, and $25 \mu \mathrm{g} \mathrm{ml}^{-1}$ amphotericin). The cells were incubated at 20 to $25^{\circ} \mathrm{C}$ in a normal atmosphere incubator, and before reaching total confluence, they were subcultured by detaching them with $1 \mathrm{ml}$ of $1: 250$ trypsin-EDTA $(10 \times)$ (Sigma) solution.

Viruses: Strains used as reference viruses included: infectious pancreatic necrosis virus (IPNV) (ATCC VR 299); IPNV strain Ab (ATCC VR 1319); IPNV strain Sp (ATCC VR 1318); IPNV strain Jasper (ATCC VR 1325); IPNV strain Tellina-2 (ATCC 1321); IPNV strain N1 (kindly supplied by Dr E. Christie, Norway); IPNV solevirus, a strain isolated at our laboratory from Solea senegalensis (Rodriguez et al. 1997); infectious haematopoietic necrosis virus (IHNV) strain ATCC VR 714; viral haemorrhagic septicemia virus (VHSV) strain D1 (kindly supplied by Dr J. L. Barja, University of Santiago, Spain); and lymphocystis disease virus (LDV) strain isolated from diseased gilt-head seabream.

Titration of the viruses was performed by the $50 \%$ tissue culture infectious dose $\left(\mathrm{TCID}_{50} \mathrm{ml}^{-1}\right)$ procedure, using 6 wells per dilution, according to the method described by Reed \& Muench (1938).

Monolayer infection: SAF-1 cells growing on 24-well plastic dishes (Costar) were tested for susceptibility to the viruses listed above. Both cytopathicity and virus replication were assessed in the cell line. Medium was removed when the monolayers possessed $90 \%$ confluence (usually $3 \mathrm{~d}$ old cultures).

The plates were inoculated in quadruplicate with $0.2 \mathrm{ml}$ well ${ }^{-1}$ of IPNV (100 TCID $50 \mathrm{ml}^{-1}$ ) suspended in serum-free medium. Viruses were adsorbed at $15^{\circ} \mathrm{C}$ for $2 \mathrm{~h}$, then the inoculum was removed, and fresh medium was added to the wells. Infected monolayers were incubated at $20^{\circ} \mathrm{C}$ and examined daily for the presence of typical cytopathic effects (CPE). A second passage of the infected monolayers was conducted when $80 \%$ of the cells showed CPE or at $7 \mathrm{~d}$ postinfection when no CPE were evident (blind passage). In this second passage, when the majority of the infected cells had detached from the plate surface, the culture media with the cells were disrupted by sonication and assayed to determine viral yields on SAF-1 cells growing on 96-well plastic dishes (Costar). The $\mathrm{BF}-2$ cell line was tested in parallel for viral replication.

Results. LDV replicates in the SAF-1 cell line produced CPE similar to those described in BF-2 cell line, i.e. an enlargement of infected cells and presence of cytoplasmic inclusions. CPE were first recorded at $3 \mathrm{~d}$ post-inoculation, although only $25 \%$ of the cells were affected. At 6 d post-inoculation, CPE extended to $50 \%$ of the cell monolayer (Table 1). The LDV strain isolated from diseased Sparus aurata replicates in SAF-1 cells and yields more viral particles than the BF- 2 cell line $\left(5 \times 10^{4}\right.$ vs $3 \times 10^{2}$ TCID $\left._{50} \mathrm{ml}^{-1}\right)$ (Table 2 ).

Both VHS and IHN rhabdoviruses and some aquabirnaviruses (IPNV) were able to replicate in the SAF-1 cell line, although significant differences among IPNV strains were observed (Table 1). CPE were recorded on the first day after inoculation with IHNV, which replicated rapidly in the new cell line. CPE of VHSV were delayed by more than $4 \mathrm{~d}$ and only $50 \%$ of the cells were affected at 6 d post-inoculation. The IPNV strains VR 299 and Sp showed slow CPE at 3 d post-inoculation, which did not progress to $75 \%$ of the cell monolayer until the 6 th day after inoculation. The strains $A b$, Jasper and Tellina-2 did not produce CPE in SAF-1 cells and infectious virus was also not recovered after 2 blind passages.

The infective titers of the viruses before adaptation to the culture in SAF-1 cells (viral passages and titrations performed in BF-2 cells) and the viral yields obtained cells after 2 successive passages in this cell line are summarized in Table 2 . The results show a high infective titer for IHNV and VHSV in both SAF-1 and $B F-2$ cell lines. The IPNV strains that replicate in SAF-1 cells yielded fewer infectious viral particles (about 100 to $1000 \mathrm{TCID}_{50} \mathrm{ml}^{-1}$ ) than rhabdovirus

Table 1. Susceptibility of SAF-1 cell monolayers at passage 72 to several fish viruses. Percentage of cells showing cytopathic effects (CPE): (0) none; $(+) 25 \%$; (++) $50 \%$; (+++) $75 \%$; $(++++) 100 \%$. TL: total lysis of cells

\begin{tabular}{|lccc|}
\hline Virus & \multicolumn{3}{c}{ Days post-inoculation } \\
& 1 & 3 & 6 \\
\hline IHNV & + & +++ & TL \\
VHSV & 0 & 0 & ++ \\
IPNV VR 299 & 0 & + & ++ \\
IPNV Sp & 0 & + & +++ \\
IPNV Ab & 0 & 0 & 0 \\
IPNV N1 & 0 & 0 & +++ \\
IPNV Jasper & 0 & 0 & 0 \\
IPNV Tellina-2 & 0 & 0 & 0 \\
IPNV solevirus & 0 & ++ & ++++ \\
LDV d & 0 & + & ++ \\
${ }^{a}$ Isolated from diseased Sparus aurata & \\
\hline
\end{tabular}


Table 2. Comparative growth of fish viruses on SAF-1 and BF-2 cell lines. Viral titers expressed as tissue culture infectious dose $\left(\mathrm{TCID}_{50} \mathrm{ml}^{-1}\right)$, nt: not tested

\begin{tabular}{|c|c|c|c|c|}
\hline \multirow[t]{2}{*}{ Viruses } & \multicolumn{2}{|c|}{$\begin{array}{l}\text { Inoculum from } \\
\text { BF-2 passage }\end{array}$} & \multicolumn{2}{|c|}{$\begin{array}{l}\text { Inoculum from } \\
\text { SAF-1 passage }\end{array}$} \\
\hline & $B F-2$ & $\mathrm{SAF}-1$ & $B F-2$ & $\mathrm{SAF}-1$ \\
\hline IHNV & $10^{8}$ & $10^{4}$ & $10^{8}$ & $10^{8}$ \\
\hline VHSV & $10^{7}$ & $10^{4}$ & $10^{7}$ & $10^{6}$ \\
\hline IPNV VR 299 & $10^{8}$ & $10^{3}$ & $10^{5}$ & $10^{3}$ \\
\hline IPNV Sp & $10^{8}$ & $10^{3}$ & $10^{5}$ & $10^{4}$ \\
\hline IPNV $\mathrm{Ab}$ & $10^{8}$ & $10^{3}$ & $<10^{1}$ & $<10^{1}$ \\
\hline IPNV N1 & $10^{6}$ & $10^{3}$ & $10^{6}$ & $<10^{1}$ \\
\hline IPNV Jasper & $10^{6}$ & $10^{3}$ & $<10^{1}$ & $<10^{1}$ \\
\hline IPNV Tellina-2 & $10^{6}$ & $10^{3}$ & $<10^{1}$ & $<10^{1}$ \\
\hline IPNV solevirus & $10^{6}$ & $10^{3}$ & $10^{6}$ & $10^{2}$ \\
\hline LDV & $\mathrm{nt}$ & nt & $10^{2}$ & $10^{4}$ \\
\hline
\end{tabular}

strains. However, infection of the BF-2 cell line, tested in parallel with the same inoculum of SAF-1 adapted virus (after 2 passages in this cell line) yielded lower amount of virus, suggesting a quick adaptation of the productive strains to the SAF-1 cell line.

As in other cell lines, the CPE produced by IPNV in SAF-1 is a characteristic feathery type, affected cells having pycnotic nucleus (Fig. 1E, F), and quite differ-

Fig. 1. Susceptibility of SAF-1 cell cultures to different salmonid fish viruses. (A) Subconfluent uninfected cells, 3 d post-inoculation; (B) beginning of VHSV CPE, $3 \mathrm{~d}$ postinoculation; (C) extensive IHNV CPE, $3 \mathrm{~d}$ post-inoculation (D) confluent uninfected cells; (E) extensive IPNV, strain VR 299 CPE, 6 d post-inoculation; (F) IPNV solevirus, advanced CPE, $6 \mathrm{~d}$ post-inoculation

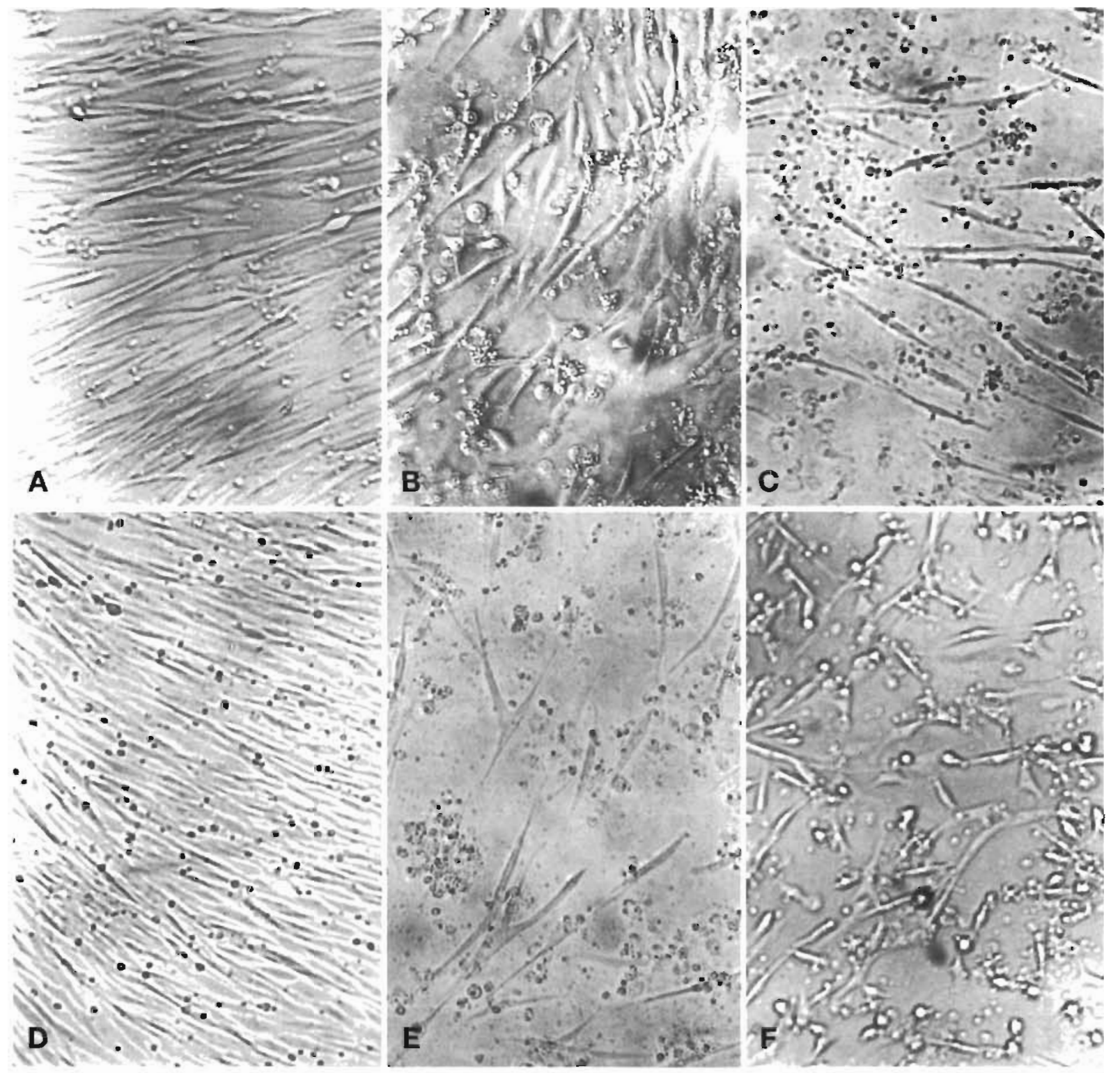


ent from that produced by IHN or VHS rhabdoviruses. However, in SAF-1 cells, IHNV produced CPE within $3 \mathrm{~d}$ post-infection that resembled the CPE of several strains of IPN virus at $6 \mathrm{~d}$ post-infection (Fig. 1C, E).

The growth of VHSV was slower and the CPE were a general rounding in grape-like fashion of cells; detached cells first appeared in the form of focal areas of rounded cells and coarsely granular debris, as in other fish cell lines (Fig. 1B).

Discussion. With the increasing recognition of the significance of viral diseases in fish populations, much interest is now being focused on the development of cell culture techniques for the diagnosis and study of latent and virulent fish viruses. The development of the SAF-1 cell line described by Bejar et al. (1997) provides a useful tool for the isolation and culture of viruses infecting gilt-head seabream Sparus aurata.

SAF-1 can grow optimally in a wide temperature range (Bejar et al. 1997), which increases its potential suitability for isolation of both warm-water and coldwater fish viruses (Nicholson et al. 1987). In addition, the use of SAF-1 has allowed us to detect and quantify lymphocystis viruses that do not replicate in standard fish cell lines, but require highly differentiated cells, such as BF-2. LDV is characterized by the development of macroscopic wart-like clusters of hypertrophic fibroblastic cells which arise from dermal integument and are usually covered by a layer of epithelium. Although there is little evidence of the disease causing mortalities in adult fish, it compromises growth and serious economic losses may occur as a consequence of infection of cultured fish, as obviously infected fish cannot be sold commercially. The occurrence of lymphocytis in natural and in aquaculture conditions indicates that contact transmission is the principal means by which this virus is spread and incubation of the disease depends on host species, virus and temperature. In cold-water hosts its presence is long lasting (visible lesions may persist for a year), while in warm-water species the cycle is often completed in several weeks. Diagnosis is usually carried out by visual examination and confirmed by histologic section, but early isolation in cell cultures and identification of the etiological agent before the lesions become apparent should be the ideal approach for avoidance and application of control measures. Although natural lymphocystis infections have been reported in several fish species, for example Archosargus probatocephalus and Stizostedion vitreum vitreum, the viruses did not infect cell lines derived from this species (Smith \& Taylor 1972. Kelly et al. 1980). In this way, the high susceptibility of the SAF-1 cells, a line derived from seabream, to LDV isolated from the same fish species is encouraging.

Studies of the ability of the SAF-1 cell line to detect salmonid viruses showed different results depending on the type of virus tested. Thus, SAF-1 was optimal to support the replication of IHNV, VHSV and some strains of IPNV. However, this cell line did not provide significant replication of the IPNV strains Ab, Jasper and Tellina-2. Descriptions of cellular resistance to some IPNV isolates are well known, as in the case of no replication of strain $\mathrm{Ab}$ in fathead minnow peduncle (FHM) cell line. The experiments described in this study were performed using IPNV strains that have been cultured in BF-2 cell line and with the same viruses after being adapted to SAF-1 cells by 2 successive passages. The results confirmed both the low susceptibility of the cell lines to Ab, Jasper and Tellina-2 strains that lost all infectivity and the quick adaptation of the other IPNV strains. This finding suggests that the natural resistance of some fish species may occur at the cellular level (Wingfield et al. 1970, Pilcher \& Fryer 1980). Nicholson et al. (1987) demonstrated variable abilities of different isolates of IPNV to replicate in different fish cell lines. In addition, in vitro studies have demonstrated that IPNV exhibit homologous interference, presumably by the generation of defectiveinterfering (DI) particles (Hedrick \& Fryer 1981). Such interference could be involved in the establishment of persistent in vitro infections, in which DI particle input and low levels of infectious viruses may be produced for a long period of time without any CPE.

In short, the present study shows the first report of lymphocystis virus replication in a marine fish cell line different than BF-2. This first cell line, derived from its specific host, gilt-head seabream Sparus aurata, offers a wide range of susceptibility for several well-known virulent salmonid viruses. Thus, it can be a useful tool in studying undetected viruses in marine species

Acknowledgements. This study was supported by Grants No. MAR-95-1949-C02-01 and 02 and No. AGF-95-016 from the Comisión Interministerial de Ciencia y Tecnologia. We appreciate the technical assistance of $M$. Sanchez.

\section{LITERATURE CITED}

Anders K (1989) Lymphocystis disease of fishes. In: Ahne W. Kurtak D (eds) Viruses of lower vertebrates. Springer, Heidelberg, p $141-160$

Basurco B, Marcotegui MA, Rueda A, Tiana A, Castellanos A, Tarazona JV, Muñoz MJ, Coll JM (1990) First report of lymphocystis disease in Sparus aurata (Linnaeus) in Spain. Bull Eur Assoc Fish Pathol 10:71-73

Bejar J, Borrego JJ, Alvarez MC (1997) A continous cell line from the cultured marine fish gilt-head seabream (Sparus aurata L.). Aquaculture 150:143-153

Berthiaume L, Alain R, Robin J (1984) Morphology and ultrastructure of lymphocystis disease virus, a fish Iridovirus, grown in tissue culture. Virology 1.35:10-19

Bruno DW, Alderman DJ, Schlotfeldt HJ (eds) (1997) What 
should I do? A practical guide for the marine fish farmer. European Association of Fish Pathologists, Aberdeen

Fenner F (1976) The classification and nomenclature of viruses. Summary of the results of meetings of the International Committee on Taxonomy of Viruses in Madrid, September 1976. J Gen Virol 31:463-470

Hedrick RF. Fryer JL (1981) Persistent infection of three salmonid cell lines with infectious pancreatic necrosis virus (IPNV). Fish Pathol 15:163-172

Kelly RK, Miller HR, Nielsen O, Clayton JW (1980) Fish cell culture: characteristics of a continous fibroblastic cell line from walleye (Stizostedion vitreum vitreum). Can J Fish Aquat Sci 37:1070-1075

Masoero L, Ercolini C, Caggiano M, Rassa A (1986) Osservazioni preliminari sulla linfocisti in una maricoltura intensiva italiana. Riv Ital Pisic Ittiopat 21:70-74

Nicholson BL, Danner DJ, Wu JL (1987) Three new continuous cell lines from marine fishes of Asia. In Vitro Cell Dev Biol 23:199-204

Nigrelli RF, Smith GM (1939) Studies on lymphocytis disease in the orange filefish, Ceratacanthus schoepfi (Walbaum) from Sandy Hook Bay, New Jersey. Zoologica 24:255-264

Paperna I, Sabrai I, Colorni A (1982) An outbreak of lymphocystis in Sparus aurata L in the Gulf of Aqaba, Red Sea. J Fish Dis 5:433-437

Perez SI, Rodriguez S (1997) Major viral diseases affecting fish aquaculture in Spain. Microbiol SEM 13:149-160

Pilcher KS, Fryer JL (1980) The viral disease of fish: a review through 1978. CRC Crit Rev Microbiol 7:297-364

Editorial responsibility: Jo-Ann Leong,

Corvallis, Oregon, USA
Reed J, Muench H (1938) A simple method of estimating fifty percent endpoints. Am J Hyg 27:493-497

Rodriguez S, Vilas P, Sarasquete MC, Rodriguez RB, Gutierrez MC, Perez SI (1997) Isolation and preliminary characterization of a birnavirus from sole Solea senegalensis in Southwest Spain. J Aquat Anim Health 9:295-300

Smith AC, Taylor RL (1972) Preliminary results of marine pathology study of the Florida Coast. Mar Technol $\mathrm{J} 6$ 51-52

Tanaka M, Yashimizu M, Kusakani M, Kimura T (1984) Lymphocystis disease in kurosoi Sebastes schligeli and hirame Paralichthys olivaceus in Hokkaido, Japan. Bul Jpn Soc Sci Fish 50:37-42

Templeman W (1965) Lymphocystis disease in American plaice of the Eastern Grand Bank. J Fish Res Board Can 22:1345-1355

Walker DP, Hill BJ (1980) Studies on the culture assay of infectivity and some in vitro properties of lymphocystis virus. J Gen Virol 51:385-395

Wingfield WH, Nims L, Fryer JL, Pilcher KS (1970) Species specificity of the sockeye salmon virus (Oregon strain) and its cytopathic effects in salmonid cell line. In: Snieszko SF (ed) A symposium in diseases of fishes and shellfishes. Am Fish Soc Spec Publ 5, Washington, DC, p 319-326

Wolf K (1988) Fish viruses and fish viral diseases. Cornell University Press, Ithaca

Wolf K. Gravel M, Malsberger R (1986) Lymphocystis virus: isolation and propagation in certrarchid fish cell lines. Science 151:1004-1005

Submitted: November 5, 1997; Accepted: October 7, 1998 Proofs received from author(s): January 7, 1999 